УДК 658.64

\title{
МОТИВАЦІЯ ПЕРСОНАЛУ В ГОТЕЛЬНОМУ ГОСПОДАРСТВІ
}

\section{MOTIVATION OF STAFF IN THE HOTEL FACILITY}

\author{
Непочатенко Валентина Олександрівна \\ кандидат економічних наук, доцент, \\ Уманський національний університет садівництва \\ ORCID: https://orcid.org/0000-0003-3495-4016
}

Nepochatenko Valentyna

Uman National University of Horticulture

\begin{abstract}
У статті розглянуто мотивуючі чинники персоналу на готельному підприємстві, проаналізовано потреби співробітників як чинника, що визначає спосіб мотивації. Досліджено, що головним фактором плинності кадрів сорери гостинності є відсутність мотивації у співробітників, які замість того, щоб докладати максимум зусиль та приносити дохід собі та компанії, змушені шукати нову роботу. Більшість таких ситуацій спричинена незадовільними умовами праці. Дисциплінарна політика та робота на межі витривалості призводить до того, що робота стає просто тягарем, і тут вже не може бути й мови про професійне, якісне обслуговування клієнтів та прояв будь-якої ініціативи з боку співробітників. Це позначається на репутації закладу, втраті постійних гостей і, зрештою, зниження прибутку. Успіх компанії - це сукупність багатьох чинників, які з часом дають свої плоди. Створення атмосфери ентузіазму, мотивації та заохочення для окремих співробітників - це те, що ви завжди потрібно дбати. Коли співробітники мотивовані працювати у команді, вони почуваються незалежними і стають продуктивнішими. Сучасні економічні умови зумовлюють постійне підвищення вимог до працівників готельних підприємств. Від них очікується більш інтенсивна робота і більш активніше та якісніше обслуговування гостей готелю. Ступінь якості виконання співробітниками поставлених завдань є прямим результатом системи мотивації та заохочення.
\end{abstract}

Ключові слова: мотивація, стимул, персонал, готель, потреби.

В статье рассмотрены мотивирующие фракторы персонала на гостиничном предприятии, проанализированы потребности сотрудников как фактора, определяющего способ мотивации. Исследовано, что главным фрактором текучести кадров сореры гостеприимства является отсутствие мотивации у сотрудников, вместо того, чтобы прилагать максимум усилий и приносить доход себе и компании, вынуждены искать новую работу. Большинство таких ситуаций вызвано неудовлетворительными условиями труда. Дисциплинарная политика и работа на грани выносливости приводит к тому, что работа становится просто обузой, и здесь уже не может быть и речи о профессиональном, качественном обслуживании клиентов и проявлении какой-либо инициативы со стороны сотрудников. Это сказывается на репутации заведения, потере постоянных гостей и, наконец, снижение прибыли. Успех компании - это совокупность многих фракторов, которые со временем приносят свои плоды. Создание атмоссреры энтузиазма, мотивации и поощрения для отдельных сотрудников - это то, что всегда нужно заботиться. Когда сотрудники мотивированы работать в команде, они чувствуют себя независимыми и становятся более продуктивными. Современные экономические условия обуславливают постоянное повышение требований к работникам гостиничных предприятий. От них ожидается более интенсивная работа и более активное и качественное обслуживание гостей отеля. Степень качества выполнения сотрудниками поставленных задач является прямым результатом системы мотивации и поощрения.

Ключевые слова: мотивация, стимул, персонал, гостиница, потребности.

The article deals with motivating factors of personnel in a hospitality enterprise, analyzes the needs of employees as a factor determining the way of motivation. It was researched that the main factor of staff turnover in the hospitality industry is the lack of motivation of employees, instead of making maximum efforts and bringing income to themselves and the company, they are forced to look for a new job. Most of these situations are caused by poor working conditions. Disciplinary policy and work on the verge of endurance leads to the fact that the job becomes just a burden, and there is no question of professional, high quality customer service and any initiative on the part of the employees. This affects the reputation of the institution, the loss of regular guests and, finally, the decrease in profits. A company's success is a combination of many factors that pay off over time. Creating an atmosphere of 
enthusiasm, motivation and encouragement for individual employees is something that should always be taken care of. When employees are motivated to work as part of a team, they feel independent and become more productive. In order to enhance material and moral incentives, the following should be taken into account: the introduction of effective systems of indicators, which should contain interrelated mechanisms of both basic and additional compensation for employees of all categories; more frequent communication between employees and directly with various levels of management; improvement of employee working conditions; the provision (or expansion) of social packages (life insurance, medical and pension insurance, payment of transportation costs and mobile communications, etc.) and the introduction of a system of incentives. In today's economic climate, the demands on hotel employees are constantly increasing. They are expected to work harder and provide more and better service to hotel guests. The extent to which employees fulfil their tasks is a direct result of the motivation and reward system. Consideration regarding the types of work motivation is constantly supplemented and modified. The topic is up-to-date and requires constant research on the varieties of its components considering the constant changes in society and personal needs of each member of the workforce, so the need to improve management, motivation and stimulation of staff, is the main way to improve the quality of work and get the most out of the employees.

Keywords: motivation, stimulus, staff, hotel, needs.

Постановка проблеми. Розширення ринку послуг та підвищення конкуренції у готельній сорері зумовлює пошук нових та якісних конкурентних переваг. В даний час, люди, що користуються послугами закладів розміщення, все більше уваги звертають не лише на стан номерів, асортимент додаткових послуг і харчування, але і на якість сервісу, тому, роль персоналу в готелі набуває все більшого значення з кожним днем.

Якщо раніше роботодавці обирали собі працівників із великої кількості кандидатів, то сьогодні все частіше самі працівники обирають найбільш привабливі для себе умови роботи. Найчастіше такі фрахівці обирають місце роботи не через заробітну плату, a, по можливості організації задовольнити їх емоційні потреби, тобто. потреби у повазі, визнанні, статусі, комфооті тощо. Тому на сьогоднішній день готельному підприємству недостатньо забезпечити працівника високою заробітною платою, преміями, використовуючи лише матеріальні елементи заохочення.

Ефрективно управляти персоналом без системи мотивації неможливо. Створення ефективної системи стимулювання персоналу в готельному бізнесі набуває особливої актуальності в умовах постійно зростаючої конкуренції.

Аналіз останніх досліджень та публікацій. Проблема мотивації працівників до праці стала предметом наукового аналізу відомих науковців: А. Афоніном, І. Бондаром, Ф. Герцбергом, Ф. Гілбретом, Т. Кір'яном, А. Колотом, Е. Лібановою, А. Маслоу, А. Смітом, Е. М. Статлером, В. Петюхом та багатьма іншими. Сьогодні проблема мотивації персоналу також знайшла широке відображення в науковій та публіцистичній літературі: А. Асронін, Д. Богиня, В. Гриньова, М. Дороніна, Г. Дмитренко, А. Єгоршин, А. Колот, О. Новікова, В. Онікієнко, Г. Цехановецький.
Виділення невирішених раніше частин загальної проблеми, й досі залишаються не розв'язаними проблеми вибору найбільш ефрективних у даний час стимулювальних важелів впливу на персонал, розроблення та застосування на готельних підприємствах мотиваційних систем, які встановлюють тісний зв'язок між заробітною платою персоналу й ефрективністю його трудової діяльності, кваліфрікацією, особистою ініціативою та сприяють найбільшому задоволенню його потреб і дозволяють модифікувати поведінку в потрібному для готельного підприємства напрямі, що приведе до досягнення поставлених цілей, як персоналу, так і підприємства.

Формулювання цілей статті. Основна мета відповісти на питання, які заходи необхідно застосовувати для підтримки та підвищення мотивації працівників, щоб вони були готові досягати цілей, поставлених перед готельним підприємством.

Виклад основного матеріалу, дослідження. Персонал готельного підприємства $€$ його найважливішим ресурсом, співробітники готелю забезпечують безпеку гостей, рівень та культуру обслуговування, створюють загальну атмоссреру у закладі.

Мотиваційний процес відбувається у тісному зв'язку із зовнішнім та внутрішнім середовищем підприємства. Основним елементом зовнішнього середовища $є$ система економічних параметрів, правових норм, політичних та соціокультурних умов. Внутрішне середовище, важливе для ефрективності мотивації, включає такі фрактори, як: розмір компанії, організаційна структура, організація роботи, умови праці та робоча атмоссрера. У готельному господарстві поділ праці та пов'язана 3 цим спеціалізація у стимулюючій діяльності залежать насамперед від розміру підприємства. На невеликих готельних підприємствах 
зазвичай власник сам опікується усім процесом управління людськими ресурсами. Він відповідає за набір та підбір працівників, за їх розвиток та мотивацію. Малий готельний бізнес часто керується сім'єю. Мотивація у таких типах організацій стосується двох внутрішніх груп: працівників, які $€$ членами сім'ї, та працівників поза сім'єю. Віддавання переваги родичам у оплаті праці та просуванню по службі на сімейних підприємствах має демотивуючий вплив на решту працівників і часто призводить до великої плинності кадрів.

Великі готельні компанії (наприклад, готельні мережі), де працюють сотні працівників, мають спеціалізовані відділи кадрів. Вони мають дуже розгалужену організаційну структуру. На цьому типі підприємств мотивацією займаються лінійні керівники та служби по персоналу. Їх участь у мотиваційному процесі охоплює більшу частину видів діяльності - від розподілу завдань між працівниками до виявлення причин диссрункцій у сфері мотивації. До завдань безпосереднього керівництва входить виявлення очікувань персоналу та оцінку рівня задоволення працівників виконаною роботою.

Служби по персоналу також займаються діяльністю, пов'язаною 3 перевіркою заходів стимулювання, що застосовуються на підприємстві. Їх роль - допомагати керівництву у виявленні порушень у сорері мотивації, розпізнаванні їх причин та розробці шляхів вирішення для покращення мотиваційного процесу.

Підприємства готельного господарства можуть використовувати два види заохочення - матеріальні та нематеріальні. У готельному господарстві базова заробітна плата зазвичай досить низька (табл. 1).

Таблиця 1

Рівень заробітної плати працівників готельної сфери, грн

\begin{tabular}{|l|c|c|}
\hline \multicolumn{1}{|c|}{ Посада } & $\begin{array}{c}\text { Середня } \\
\text { по Україні }\end{array}$ & м. Київ \\
\hline Менеджер по бронюванню & 15000 & 17500 \\
\hline Швейцар & 9000 & 14000 \\
\hline Покоївка & 9900 & 11000 \\
\hline Хостес & 12500 & 15000 \\
\hline Адміністратор готелю & 10000 & 12500 \\
\hline Аніматор & 9500 & 20000 \\
\hline Консьєрж & 6500 & 6800 \\
\hline \multicolumn{3}{|c|}{ Джерело: [5] } \\
\hline
\end{tabular}

Дані таблиці вказують на те, що рівень заробітної плати коливається. залежно від місця розташування закладу.
Кваліфрікаційні вимоги до офріціантів готельно-ресторанних комплексів, згідно 3 ДСТУ 4269:2003, до обслуговуючого персоналу та його підготовленості, серед інших, $€$ вільне володіння англійською мовою. Багато людей мають хибне уявлення про те, що робота офріціанта або покоївки не потребує особливих знань та досвіду. Непрофресійне i, як наслідок, неякісне надання послуг призводить до конфліктів, зниження репутації готелю/ресторану і зрештою - до зниження завантаження готельного фонду, посадкових місць ресторану і втрати підприємством прибутку [2, с. 324].

Види матеріальної винагороди мають значну мотиваційну фрункцію, вони включають: комісії, бонуси, нагороди, підказки. Щоб збільшити активність працівника щодо залучення гостей та збільшити кількість замовлень, роботодавець може використовувати систему комісійних. Комісія виплачується працівникам, які мають безпосередній вплив на бронювання, тобто адміністраторам та працівникам відділу бронювання, а також працівникам відділу громадського харчування: офріціантам, барменам, менеджерам бенкетів тощо. Бонуси є мотивуючим фрактором для працівників, які не мають прямого контакту з гостем, наприклад, з відділів маркетингу, адміністрації та бухгалтерії. Премія залежить від фрінансового результату, а також якості роботи цих працівників. Ще одним мотивуючим фрактором $€$ премії, що призначаються в конкретних випадках, наприклад, коли працівник проявив себе під час надзвичайної ситуації - раптова хвороба гостя, крадіжка, пожежа.

До мотивуючих чинників також належать чайові. Хоча вони не мають прямого відношення до роботодавця, але вони можливі завдяки умовам, які роботодавець створює, так як висока категорія та гарна репутація готелю зазвичай впливає на розмір чайових.

Інші матеріальні мотиваційні фрактори, що не пов'язані 3 виплатою грошей, включають фрізичні умови праці (наприклад, належне освітлення робочого місця, ефективне та сучасне обладнання, чисті та естетичні гардероби, робочий одяг), медичне обслуговування (наприклад, контракт 3 приватною клінікою, послугами якого можуть скористатися співробітників та їх сім'ї), страхування життя, можливості виїзду за кордон у межах групи готелів.

Важливу роль у мотивації працівників відіграють зустрічі з керівництвом готелю, під час зустрічей з співробітником, особливо тим, хто вступає в перший контакт, засвідчують, що 
вони відповідальні за створення першого та останнього враження про компанію. Ці зустрічі впливають не тільки на якість роботи, але і на рівень задоволеності персоналу. Завдяки таким зустрічам працівники відчувають, що керівництво їх цінує та поважає. Під час зустрічей співробітники можуть висловлювати свою думку чи вносити пропозиції, дізнаватися, як поводитись у складних ситуаціях (наприклад, крадіжка, дуже засмучений гість). Такі зустрічі також об'єднують працівників, оскільки це можливість обміну досвідом.

При створенні мотиваційної системи велике значення слід надавати підготовці заходів, що активізують персонал для досягнення цілей готельного підприємства. Водночас важливо, щоб під час вибору конкретних мотиваторів враховувалися потреби співробітників. Їх можна розглядати у двох вимірах: профресійному та особистому. Профресійні потреби пов'язані 3 належністю до конкретної організації та реалізацією в ній конкретних завдань. Вони також безпосередньо пов'язані 3 особистими потребами. На практиці всі потреби працівників відповідають базовим рівням, визначеним Авраамом Маслоу, тобто фрізіологічним потребам, безпеці, приналежності, повазі та визнанню, самореалізації.

Взаємозв'язок роботи 3 фрізіологічними потребами є очевидний. В основному завдяки роботі люди отримують засоби для їх задоволення. Потреби в їжі, воді, сні з'являються регулярно, і їх не можна ігнорувати занадто довго. Робота - це не тільки засіб, а й місце для задоволення фрізіологічних потреб. Тому питання соціальних та побутових умов, а також безпеки та гігієни мають особливе значення. Задоволення цієї потреби також включає питання пристосування робочих місць до психофрізичних особливостей та здібностей особи.

Наступна група - це потреби безпеки. Особливо вона активізується, в нових ситуаціях. Вихід на першу роботу в житті викликає у працівника занепокоєння, чи впорається він з незнайомими обов'язками, чи зможе адаптуватися до нового соціального середовища. Подібні почуття супроводжують професійні підвищення та організаційні зміни. Нові ситуації породжують невпевненість, іноді навіть страх. У літніх працівників може зростати занепокоєння щодо відсутності професійної придатності. Їх причиною зазвичай $€$ зниження фрізичної та розумової працездатності, а також «старіння» профресійної кваліфікації.

Наступним рівнем у піраміді Маслоу $\epsilon$ потреби у належності (належність до групи).
Вони пов'язані 3 соціальною природою людини і проявляються в пошуку позитивних зв'язків 3 іншими людьми. У соціальних контактах ми відчуваємо почуття товариськості, дружби та кохання. Прихід до професійної роботи дає можливість відчути новий тип соціальних контактів. Співробітник відчуває себе членом певної компанії та групи працівників. На думку А. Маслоу, потреба у приналежності особливо сильна у молодих людей. Це робить їх становище ще більш складним, якщо вони не будуть прийняті або відхилені групою старших працівників. Це зіткнення очікувань і реальності є однією з причин частої зміни персоналу з досвідом роботи не більше одного року. Тому в процесі профресійної адаптації велике значення слід надавати створенню умов, що сприяють виникненню позитивних зв'язків між новими та довгостроковими учасниками організації.

Важливість потреб поваги серед людей значною мірою залежить від типу культури. Сучасна американська та європейська культура орієнтована на успіх - вони фрормують та зміцнюють прагнення виділитися, досягти успіху, кар'єри та досягнень у будь-якій сорері. Більшість людей працюють для отримання прибутку. Гроші є одним 3 найбільш універсальних засобів задоволення інших потреб. Це також стосується потреби в повазі. Це пояснюється тим, що багато людей розглядають розмір заробітку як показник визнання профресії, освіти, навичок та результатів, досягнутих на роботі. Бажання збільшити дохід та готовність демонструвати зовнішні ознаки престижу істотно впливають на мотивацію до роботи. Напрямок цього впливу, однак, залежить від багатьох інших фракторів, таких як, наприклад, реальні та передбачувані можливості зростання доходів за рахунок збільшення заробітку, а останні за рахунок поліпшення результатів, фрактичні та передбачувані можливості придбання бажаних товарів. Використання мотиву суспільного визнання як чинника підвищення мотивації до праці також полягає у побудові привабливих шляхів (закономірностей) кар'єрного розвитку учасників організації. Вони інфрормують усіх про можливості та умови просування по службі. Вони також створюють основу для порівняння індивідуальних успіхів чи невдач.

Остання група потреб, що посідає верхнє місце в ієрархії Маслоу - це самореалізація. Майже у кожної людини є улюблене заняття, яке найчастіше пов'язане з реалізацією своїх інтересів та потенційних можливостей. Вико- 
нуючи їх, він розвивається. Прагнення до самореалізації $€$ важливим мотиватором. Як правило, працівник 3 такою активованою потребою добре виконує свої завдання, не пов'язуючи власну діяльність безпосередньо і занадто тісно з рівнем заробітку. Самостійний працівник на роботі неохоче змінює тип виконуваної роботи та виконує завдання, незважаючи на тимчасові труднощі. Самореалізація більше пов'язана із задоволенням працівника самою дією, яку він любить виконувати, та участю у процесі створення чогось, ніж із кінцевим результатом та отриманою оцінкою (похвала, винагорода). Однією з важливих умов, що сприяють самореалізації працівників, $€$ надання їм адекватної свободи дій (з точки зору потреб та можливостей підприємства). Потреби працівників готельних підприємств відповідають базовим рівням ідентифрікованих Авраамом Маслоу.

Висновки. Правильно застосована мотивація вимагає від керівників відповідних знань про людей, соціальні групи, економічні проблеми підприємства та його оточення i, насамперед, регулярного дослідження фракторів, що мотивують співробітників. В деяких напря- мах мотиваційної діяльності, що вимагають певних змін в готельних підприємствах, були виділені такі:

- завдання, пов'язані з визначенням очікувань працівників щодо роботи;

- комунікації в галузі мотивації, недоліки яких в основному з'являються у відсутності відповідних рішень щодо інфрормування працівників про цілі підприємства, відповідно до яких ставляться завдання та критерії оцінки при їх досягненні,

- заходи, спрямовані на розпізнавання дисфрункцій мотиваційного процесу та виявлення їх причин.

Ефективна мотивація - це постійна, безперервна робота з дослідженням потреб персоналу та спостереження за їх поведінкою на роботі. Ключем до розуміння $€$ знання їхніх життєвих ситуацій та потреб - як особистих, так і професійних. Це можливо завдяки побудові відносин між підлеглим та керівником, які дозволяють зрозуміти переваги, потреби та мотиви людини.

На досвіді доведено, що ставлення співробітника до своїх обов'язків прямо пропорційне ставленню роботодавця до співробітника.

\section{СПИСОК ВИКОРИСТАНИХ ДЖЕРЕЛ:}

1. Занюк С. Психологія мотивації. Київ : Либідь, 2019.

2. Коваленко Л.Г. Мотивація персоналу підприємств готельно-ресторанного господарства. Економіка та управління підприємствами. 2018. № 16. C. 323-326. URL: http://global-national.in.ua/archive/16-2017/66.pdf

3. Крушельницька О., Мельничук Д. Управління персоналом. Київ : Кондор, 2013.

4. Мушкін І. Нематеріальна мотивація продуктивності праці. Персонал. 2019. № 4. С. 44-49.

5. Статистика зарплат в Україні. Средняя зарплата по категории «Гостинично-ресторанный бизнес, туризм» в Украине. URL: https://www.work.ua/ru/salary-hotel-restaurant-tourism/?page=1

\section{REFERENCES:}

1. Zanyuk S. (2019) Psychology of motivation. Kyiv: Lybid. (in Ukrainian)

2. Kovalenko L.G. (2017) Motivation of the personnel of the enterprises of hotel and restaurant economy. Economics and Enterprise Management, 16, 323-326. Retrieved from: http://global-national.in.ua/archive/16-2017/66.pdf (in Ukrainian)

3. Krushelnytska O., Melnychuk D. (2013) HR. Kyiv: Condor. (in Ukrainian)

4. Mushkin I. (2019) Intangible motivation of labor productivity. Personnel, 4, 44-49. (in Ukrainian)

5. Wage statistics in Ukraine. The average salary in the category "Hotel and restaurant business, tourism" in Ukraine. Retrieved from: https://www.work.ua/ru/salary-hotel-restaurant-tourism/?page=1 